\section{Determining the Effect of Carrier Water pH and Bicarbonate Concentration on Final pH of Plant Growth Regulator Solutions}

\author{
Diane M. Camberato \\ Department of Horticulture and Landscape Architecture, Purdue University, \\ 625 Agriculture Mall Drive, West Lafayette, IN 47907-2010
}

James J. Camberato

Department of Agronomy, Purdue University, West Lafayette, IN 47907-2054

Roberto G. Lopez ${ }^{1,2}$

Department of Horticulture and Landscape Architecture, Purdue University, 625 Agriculture Mall Drive, West Lafayette, IN 47907-2010

Additional index words. alkalinity, buffer capacity, floriculture, greenhouse crops, PGRs, water quality

\begin{abstract}
Chemical plant growth regulators (PGRs) are important tools in greenhouse ornamental crop production because growers must increasingly meet specifications for plant shipping and marketability. However, the role of water quality parameters such as pH or alkalinity (bicarbonate in this study) on final PGR solution pH is not well documented and could impact efficacy. We assessed the interaction of PGR type and concentration on the final spray solution $\mathrm{pH}$ when combined with carrier water of varying $\mathrm{pH}$ and bicarbonate concentration. Eleven PGRs commonly used in floriculture (ancymidol, benzyladenine, chlormequat chloride, daminozide, dikegulac-sodium, ethephon, flurprimidol, gibberellic acid, gibberellic acid/benzyladenine, paclobutrazol, and uniconazole) at three concentrations (low, medium, and high recommended rates for each product) were added to reverse osmosis (RO) carrier water adjusted to four $\mathrm{pH}$ (5.3, 6.2, 7.2, 8.2) levels or added to tap carrier water adjusted to four bicarbonate concentrations $\left(40,86,142,293 \mathrm{mg} \cdot \mathrm{L}^{-1}\right.$ of $\left.\mathrm{CaCO}_{3}\right)$. Resultant solution pH levels were measured. Plant growth regulators were categorized as acidic, neutral, or basic in reaction based on the change of the carrier water $\mathrm{pH}$ on their addition. Benzyladenine, chlormequat chloride, gibberellic acid, and gibberellic acid/benzyladenine acted as weak acids when added to RO water, whereas daminozide, ethephon, and uniconazole reduced final solution pH from 1.25 to $5.75 \mathrm{pH}$ units. Flurprimidol and paclobutrazol were neutral in reaction with final solution $\mathrm{pH}$ being similar to that of the $\mathrm{RO}$ carrier water before their addition. Ancymidol and dikegulac-sodium were basic in reaction, increasing final solution $\mathrm{pH}$ in $\mathrm{RO}$ carrier water up to 2.3 units. There was an interaction between chlormequat chloride concentration and $\mathrm{RO}$ carrier water $\mathrm{pH}$ on change in $\mathrm{pH}$. When added to tap carrier water, final solution $\mathrm{pH}$ increased for all except the stronger acids, daminozide, ethephon, and uniconazole, where it decreased up to 3.5 units, and benzyladenine, where it decreased 0.35 units at $40 \mathrm{mg} \cdot \mathrm{L}^{-1}$ bicarbonate. There was an interaction between PGR concentration and bicarbonate concentration in tap carrier water for daminozide and ethephon. The magnitude of change in $\mathrm{pH}$ (final solution pH minus initial carrier water $\mathbf{p H}$ ) with the addition of each PGR was greater for RO than for tap water containing 40 to $293 \mathrm{mg} \cdot \mathrm{L}^{-1}$ bicarbonate for all 11 PGRs tested.
\end{abstract}

\footnotetext{
Received for publication 16 Jan. 2014. Accepted for publication 10 July 2014.

We gratefully acknowledge Dana Williamson and Camille Mahan for laboratory assistance; funding from growers providing support for Purdue University floriculture research, Fine Americas, Inc., and OHP, Inc.; and support from the Purdue Agricultural Experiment Station and USDA-NIFA. Use of trade names in this publication does not imply endorsement by Purdue University of products named nor criticism of similar ones not mentioned.

${ }^{1}$ Associate Professor and Extension Specialist.

${ }^{2}$ To whom reprint requests should be addressed; e-mail rglopez@purdue.edu.
}

Chemical PGRs are commonplace in the horticulture industry, having been used commercially since the 1940s (Nickell, 1994). In high-value floriculture crops, PGRs are used in combination with cultural and environmental control methods to produce crops meeting increasingly specific market window and size specifications. The short production time of annual bedding plants in 10 - to $15-\mathrm{cm}$ diameter containers and the marketing advantage of compact plants (improved branching and structure) in flower (earlier and more uniform) and with improved shelf life have contributed to the necessity of using chemical
PGRs in the bedding plant industry (Barrett, 2006; Bell, 2001). There is also the possibility of additional benefits derived from PGR application: disease reduction, enhanced foliage color, and increased water use efficiency that contributes to their continued use (Whipker, 2013).

Much research has been conducted on efficient chemical PGR application: timing of application, application method and rates, target tissues, environmental conditions at application, and dosage (Whipker et al., 2003). Spray solution water quality, particularly $\mathrm{pH}$ and alkalinity [presence of bicarbonates $\left(\mathrm{HCO}_{3}{ }^{-}\right)$and carbonates $\left.\left(\mathrm{CO}_{3}{ }^{-2}\right)\right]$, may also play a role in PGR efficiency. Growth regulator solutions made with high $\mathrm{pH}$ (greater than 7.0) or highly buffered (greater than $100 \mathrm{mg} \cdot \mathrm{L}^{-1} \mathrm{CaCO}_{3}$ ) carrier water may reduce effectiveness, as suggested by Hammer (2001). A grower survey (Burns, 2004) indicated that $60 \%$ of respondents were aware of potential water quality effects on chemical PGRs and that $45 \%$ had a water treatment system in place, typically acid injection to lower $\mathrm{pH}$ and neutralize bicarbonates. Water used in U.S. greenhouse production facilities has traditionally come from groundwater wells (Biernbaum, 1999). Because many growers do not use a water treatment system, carrier water for PGR spray solutions can be variable in $\mathrm{pH}$ and buffering capacity. Research documents water quality effects on herbicides and insecticides, particularly in agronomic crops, but there is little research detailing how the $\mathrm{pH}$ or alkalinity aspects of water quality influence PGRs in horticultural crops. For example, phytotoxicity from glyphosate was reduced when mixed in carrier water with high concentrations of calcium and bicarbonate (Buhler and Burnside, 1983). Carrier water $\mathrm{pH}$ greater than 7.0 can cause weak acid herbicides such as glyphosate, 2,4-D, and dicamba to become negatively charged $\left(\mathrm{OH}^{-}\right.$from water accepts $\mathrm{H}^{+}$from chemical) decreasing absorption by the leaf cuticle and cell membrane (Chahal et al., 2012). Insecticides and miticides are also sensitive to carrier water alkalinity, and alkaline hydrolysis can occur when spray solution $\mathrm{pH}$ is greater than 7.0 (Cloyd, 2007). Mudge and Swanson (1978) found that ethylene release from ethephon was dependent on solution $\mathrm{pH}$ and that the addition of buffers increased ethylene concentration to cuttings of Phaseolus aureus Roxb. (mung bean).

There is little information available on the reaction of the PGRs widely used in bedding plant production to carrier water $\mathrm{pH}$ and bicarbonate concentration. The objective of this study was to quantify the effects of carrier water $\mathrm{pH}$, bicarbonate concentration, and PGR concentration on the final solution $\mathrm{pH}$ of 11 PGRs labeled for horticultural use. Final solution $\mathrm{pH}$ was compared with the recommended $\mathrm{pH}$ range for optimum PGR performance as indicated by manufacturer (Table 1) or Yates et al. (2011). 


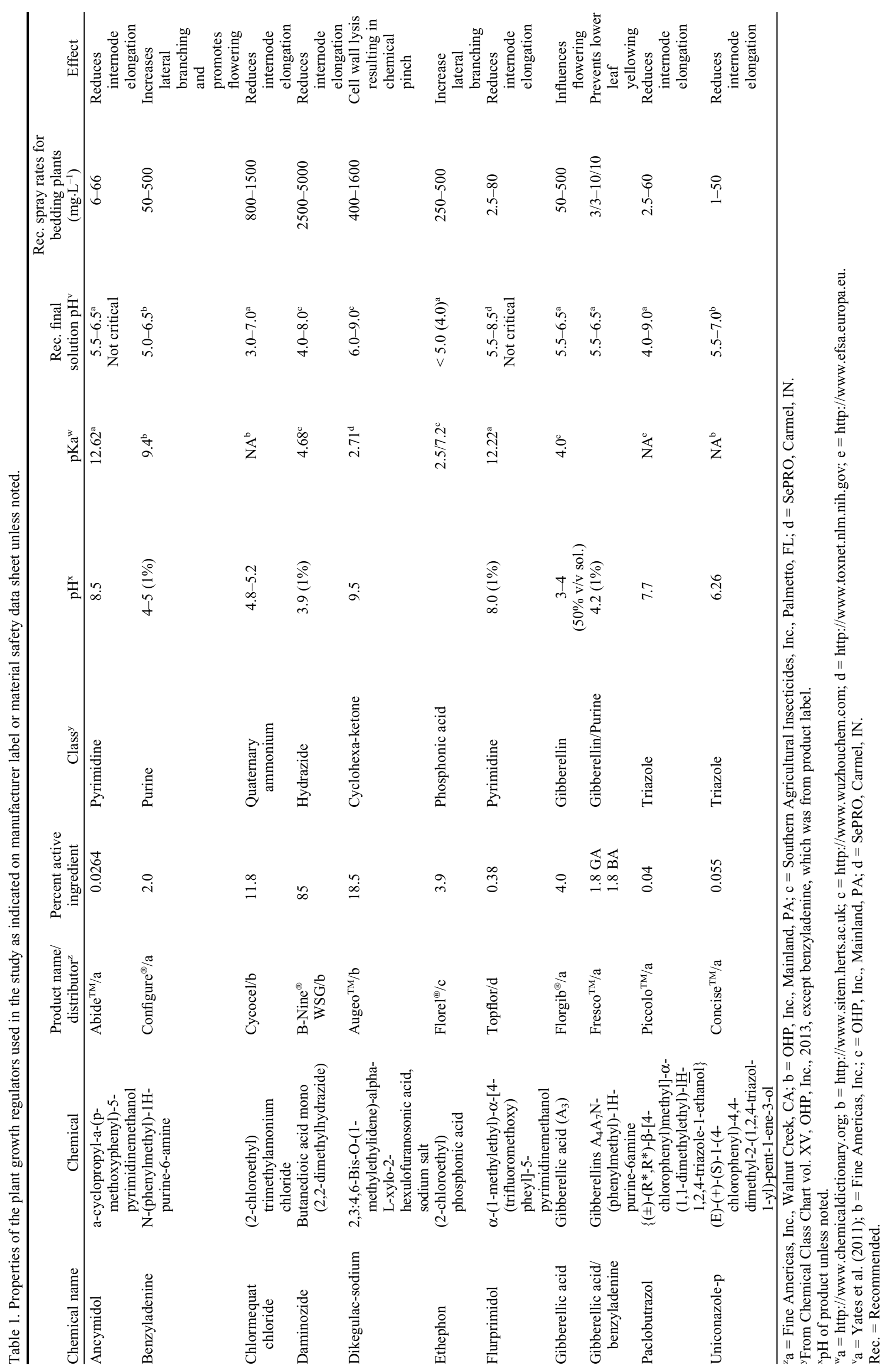




\section{Materials and Methods}

Initial carrier water characteristics. Because water is used as the carrier for the application of PGRs, the term carrier water will be used to distinguish initial water qualities before PGR addition from final solution water characteristics after PGR addition. Samples of well water from the Wabash River Valley aquifer (to be referred to as tap) were placed in 1-pint polypropylene containers filled completely to eliminate air, sealed tightly, and shipped the same day to a commercial laboratory (Sherry Laboratories, Fort Wayne, IN) in March of 2011 (Replication 1) and in June 2012 (Replication 2) for analysis. Results of Replications 1 and 2 were similar and thus data were pooled. Tap water alkalinity [determined by the amount of carbonate $\left(\mathrm{CO}_{3}{ }^{-2}\right)$ and bicarbonate $\left(\mathrm{HCO}_{3}{ }^{-}\right)$present] were determined by the SM (20th)-2320B method (Clescerl et al., 1998). Because the amount of carbonate was negligible, alkalinity is represented by the amount of bicarbonate $\left(293 \mathrm{mg} \mathrm{CaCO}_{3} / \mathrm{L}\right)$ and thus the term bicarbonate will be used. Average $\mathrm{pH}$ was 7.34 as measured by the SM (20th)-4500- $\mathrm{H}^{+}$B method (Clescerl et al., 1998). Other tap water characteristics were (in $\mathrm{mg} \cdot \mathrm{L}^{-1}$ ) 0.3 nitrogen, 0.5 phosphorus, 65 $\mathrm{SO}_{4}-\mathrm{S}, 96$ calcium, 3 potassium, 34 magnesium, 0.1 iron, 0.2 manganese, 9 sodium, 33 chlorine, and less than 0.1 boron. ALKCALC (UNH, 2009) was used to determine the amount of $96 \%$ sulfuric acid $\left(\mathrm{H}_{2} \mathrm{SO}_{4}\right)$ (Mallinckrodt Chemicals, Phillipsburg, NJ) to add to tap water to achieve target bicarbonate concentrations of $\approx 295,150,75$, and $35 \mathrm{mg} \mathrm{CaCO}_{3} / \mathrm{L}$. Actual bicarbonate concentrations were $293,142,86$, and 40 $\mathrm{mg} \mathrm{CaCO}_{3} / \mathrm{L}$ at $\mathrm{pH} 7.3,6.2,5.8$, and 5.4, respectively (average of two replications; same laboratory and methods as for initial samples).

Reverse osmosis water was analyzed as reported previously. Results of Replications 1 and 2 were similar with an average $\mathrm{pH}$ of 6.3 and bicarbonate concentration of $11 \mathrm{mg}$ $\mathrm{CaCO}_{3} / \mathrm{L}$; cations and anions were negligible, so values are not presented. Additions of $0.1 \mathrm{~N}$ potassium hydroxide $(\mathrm{KOH})$ (Mallinckrodt Baker, Phillipsburg, NJ) or $0.1 \mathrm{~N} \mathrm{H}_{2} \mathrm{SO}_{4}$ were made to $\mathrm{RO}$ water to achieve target solutions of $\mathrm{pH} 8.2,7.2,6.2$, and 5.2. Actual solution $\mathrm{pH}$ averaged for the two replications was 8.2, 7.2, 6.2, and 5.3 (Table 3; Fig. 3).

Plant growth regulator treatments. The effect of ancymidol (AC), benzyladenine (BA), chlormequat chloride (CC), daminozide (DZ), dikegulac-sodium (DS), ethephon (EP), flurprimidol (FP), gibberellic acid (GA), gibberellic acid/benzyladenine (GA/BA), paclobutrazol (PB), and uniconazole (UC) (Table 1) on final solution $\mathrm{pH}$ was evaluated at three solution concentrations based on suggested low, medium, and high rates (Table 2) used for foliar spray application on bedding plants. Growth regulators were added using a pipette-lite (Rainin Instruments, LLC, Oakland, CA) to $100 \mathrm{~mL}$ of carrier tap or RO water at each bicarbonate
Table 2. Active ingredient concentration of final solutions for ancymidol, benzyladenine, chlormequat chloride, daminozide, dikegulac-sodium, ethephon, flurprimidol, gibberellic acid, gibberellic acid/ benzyladenine, paclobutrazol, and uniconazole at listed chemical concentrations.

\begin{tabular}{|c|c|c|}
\hline $\begin{array}{l}\text { Percent active ingredient } \\
\text { in product }\end{array}$ & $\begin{array}{l}\text { Product concn } \\
\quad\left(\mathrm{mL} \cdot \mathrm{L}^{-1}\right)\end{array}$ & $\begin{array}{l}\text { Active ingredient in final } \\
\text { solution }\left(\mathrm{mg} \cdot \mathrm{L}^{-1}\right)\end{array}$ \\
\hline \multirow[t]{3}{*}{0.026 ancymidol } & 57.72 & 15 \\
\hline & 115.40 & 30 \\
\hline & 173.12 & 45 \\
\hline \multirow[t]{3}{*}{2.0 benzyladenine (6-BA) } & 7.52 & 150 \\
\hline & 15.00 & 300 \\
\hline & 22.52 & 450 \\
\hline \multirow[t]{3}{*}{11.8 chlormequat chloride } & 6.78 & 800 \\
\hline & 12.71 & 1500 \\
\hline & 18.64 & 2200 \\
\hline \multirow[t]{3}{*}{85.0 daminozide } & $1.76 \mathrm{~g}$ & 1500 \\
\hline & $3.53 \mathrm{~g}$ & 3000 \\
\hline & $5.29 \mathrm{~g}$ & 4500 \\
\hline \multirow[t]{3}{*}{18.5 dikegulac-sodium } & 2.16 & 400 \\
\hline & 4.32 & 800 \\
\hline & 6.48 & 1200 \\
\hline \multirow[t]{3}{*}{3.9 ethephon } & 6.41 & 250 \\
\hline & 12.82 & 500 \\
\hline & 19.23 & 750 \\
\hline \multirow[t]{3}{*}{0.38 flurprimidol } & 5.26 & 20 \\
\hline & 10.53 & 40 \\
\hline & 21.05 & 80 \\
\hline \multirow[t]{3}{*}{4.0 gibberellic acid $\left(\mathrm{GA}_{3}\right)$} & 0.625 & 25 \\
\hline & 1.25 & 50 \\
\hline & 1.875 & 75 \\
\hline \multirow{3}{*}{$\begin{array}{l}1.8 / 1.8 \text { gibberellic acid/ } \\
\text { benzyladenine }\left(\mathrm{GA}_{4+7} / 6-\mathrm{BA}\right)\end{array}$} & 0.056 & $1 / 1$ \\
\hline & 0.278 & $5 / 5$ \\
\hline & 0.556 & $10 / 10$ \\
\hline \multirow[t]{3}{*}{0.4 paclobutrazol } & 3.75 & 15 \\
\hline & 7.50 & 30 \\
\hline & 11.25 & 45 \\
\hline \multirow[t]{3}{*}{0.055 uniconazole } & 18.18 & 10 \\
\hline & 45.46 & 25 \\
\hline & 72.73 & 40 \\
\hline
\end{tabular}

concentration or $\mathrm{pH}$ level, respectively, in a $250-\mathrm{mL}$ erlenmeyer flask. Plant growth regulator solutions were stirred continuously while $\mathrm{pH}$ was measured with an Orion 5 Star $\mathrm{pH}$ meter and Ross Ultra ${ }^{\circledR}$ Combination $\mathrm{pH}$ electrode (Thermo Scientific, Beverly, MA). Final solution $\mathrm{pH}$ was measured twice per replication, $\approx 45 \mathrm{~min}$ apart, and the average value was used for statistical analysis.

Data collection and analysis. The 11 PGRs at three concentrations were added to RO water adjusted to four initial $\mathrm{pH}$ levels with four replications of each treatment (264 individual solutions). As a result of the abundance of treatments and the time required to mix each treatment, treatments and measurements were made over a 3-d period beginning late Apr. 2011 for Replication 1 and late June 2012 for Replication 2. Three to four PGRs were evaluated each day. The 11 PGRs at the same three concentrations were also added to tap water adjusted to four initial bicarbonate concentrations with four replications of each treatment (264 individual solutions). Treatments and measurements were made over a 3-d period beginning early May 2011 for Replication 1 and early July 2012 for Replication 2 with three to four PGRs evaluated each day. Each PGR-water type combination was an experiment with PGR concentration and initial carrier water $\mathrm{pH}$ (RO water) or bicarbonate concentration (tap water) as treatment variables. Each treatment was replicated twice in a completely randomized design. Analysis of variance and means separations (least significant difference) were calculated with PROC GLM (SAS Institute, Cary, NC) and considered significant at $P \leq 0.05$.

\section{Results and Discussion}

The 11 PGRs studied were classified based on their acidity, basicity, or neutrality as determined by the effect (predominant direction of $\mathrm{pH}$ movement) of the PGR on final solution $\mathrm{pH}$ (Figs. 1 to 4 ) regardless of initial carrier water $\mathrm{pH}$ or $\mathrm{PGR}$ concentration.

Ancymidol was basic in reaction as final solution $\mathrm{pH}$ increased in $\mathrm{RO}$ water for all but 


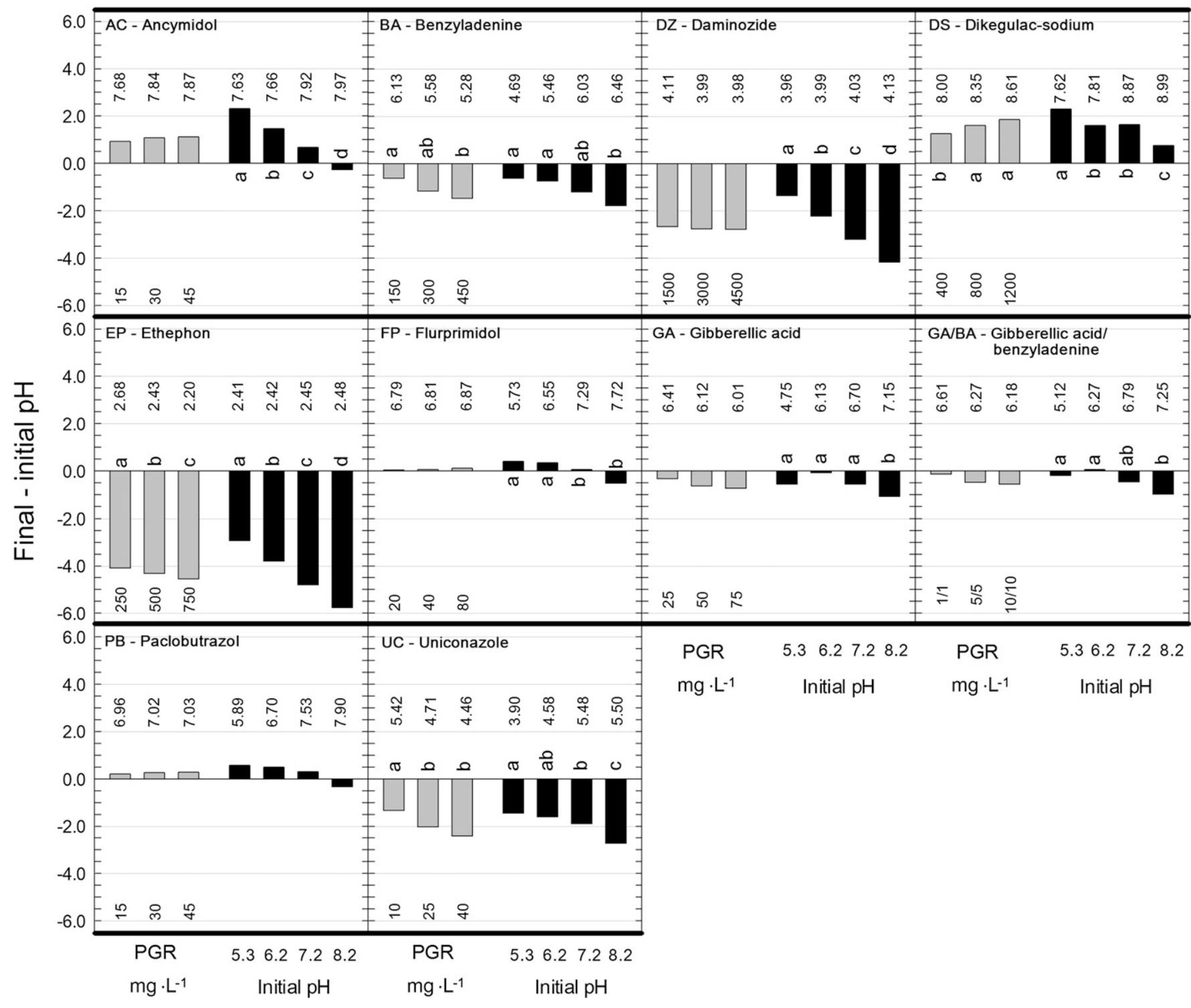

Fig. 1. Main effects of plant growth regulator (PGR) solution concentration and initial carrier water (reverse osmosis) $\mathrm{pH}$ on change in $\mathrm{pH}$ (final solution $\mathrm{pH}$ minus initial carrier water solution $\mathrm{pH}$ ). Final $\mathrm{pH}$ values are shown above each column and PGR solution concentrations are shown below each column. PGRs were ancymidol, benzyladenine, daminozide, dikegulac-sodium, ethephon, flurprimidol, gibberellic acid, gibberellic acid/benzyladenine, paclobutrazol, and uniconazole. Columns within each treatment variable without letters or with the same letter indicate no significant treatment effects $(P>0.05)$. Columns within each treatment variable with different letters indicate significant treatment differences $(P \leq 0.05)$.

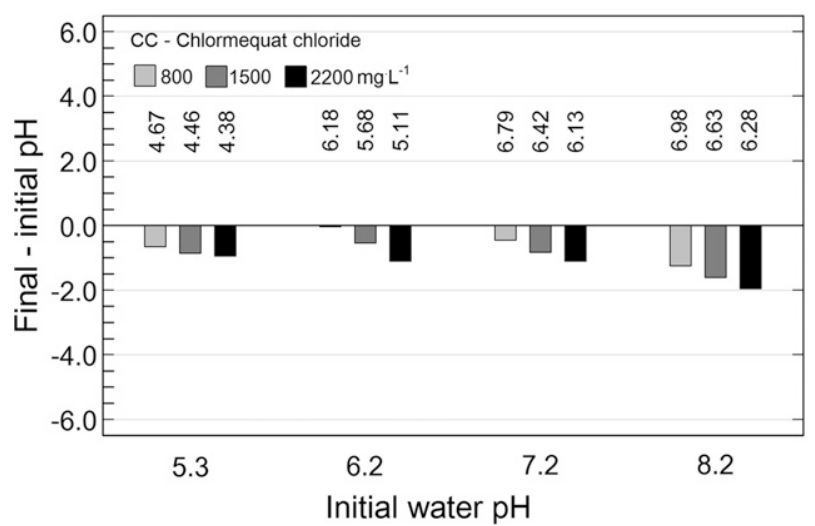

Fig. 2. Change in $\mathrm{pH}$ (final solution $\mathrm{pH}$ minus initial carrier water $\mathrm{pH}$ ) for interaction of chlormequat chloride at three concentrations and four initial $\mathrm{pH}$ values in reverse osmosis $(\mathrm{RO})$ water. Final solution $\mathrm{pH}$ values are shown above each column. the highest initial $\mathrm{pH}$ level of 8.2 (Fig. 1). The greatest $\mathrm{pH}$ change $(+2.2$ units) occurred at a carrier $\mathrm{pH}$ of 5.3 (Table 3; Fig. 1). The small range of final solution $\mathrm{pH}$ values (7.6 to 8.0 ) across a wide range of initial $\mathrm{pH}$ levels indicates a strong buffering of the solution. There was no significant $\mathrm{pH}$ change when PGR concentration was increased from 15 to $45 \mathrm{mg} \cdot \mathrm{L}^{-1}$ although the volume of $\mathrm{AC}$ added went from 58 to $173 \mathrm{~mL} \cdot \mathrm{L}^{-1}$ (Table 2), another indication of a strongly buffered solution. When AC was added to tap water, the change in final solution $\mathrm{pH}$ diminished by one unit as bicarbonate concentration increased from 40 to $293 \mathrm{mg} \mathrm{CaCO}_{3} / \mathrm{L}$ and final solution $\mathrm{pH}$ was less than values with RO water (Table 3; Fig. 3).

Benzyladenine was acidic in reaction. In RO water, the change in $\mathrm{pH}$ decreased 0.5 to 1.75 units as BA concentration and carrier water $\mathrm{pH}$ increased (Table 3; Fig. 1). With tap 


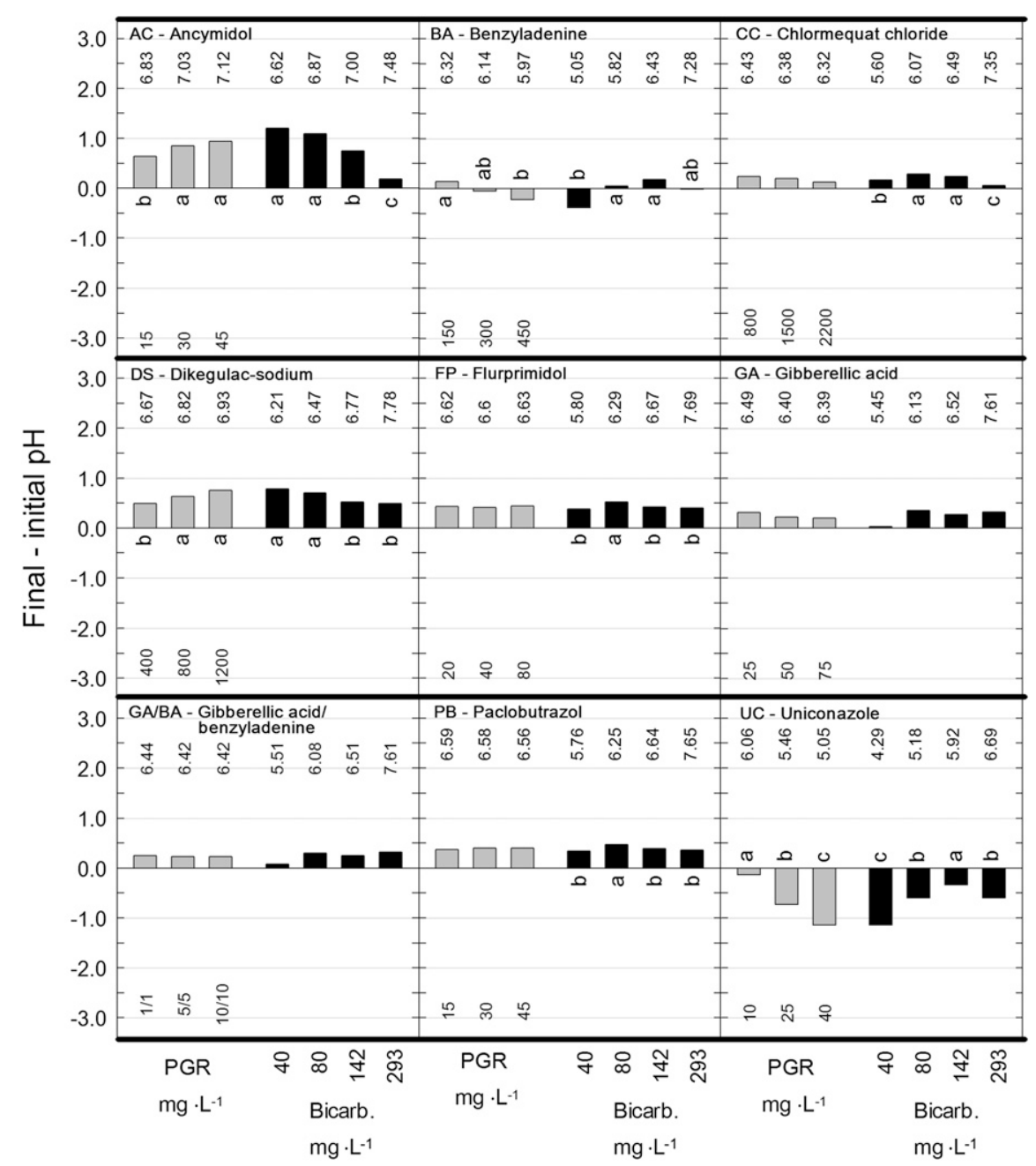

Fig. 3. Main effects of plant growth regulator (PGR) solution concentration and initial carrier water (tap water) bicarbonate concentration on change in $\mathrm{pH}$ (final solution $\mathrm{pH}$ minus initial carrier water $\mathrm{pH}$ ). Final $\mathrm{pH}$ values are shown above each column and PGR solution concentrations are shown below each column. PGRs were ancymidol, benzyladenine, chlormequat chloride, dikegulac-sodium, flurprimidol, gibberellic acid, gibberellic acid/benzyladenine, paclobutrazol, and uniconazole. Columns within each treatment variable without letters or with the same letter indicate no significant treatment effects $(P>$ 0.05). Columns within each treatment variable with different letters indicate significant treatment differences $(P \leq 0.05)$.

water containing bicarbonate, adding BA had little effect on final solution $\mathrm{pH}$ (Table 3; Fig. 3), suggesting it was as a weak acid.

Chlormequat chloride was acidic in RO water but weakly basic in tap water. The effect of PGR concentration on final solution $\mathrm{pH}$ was dependent on $\mathrm{RO}$ carrier water $\mathrm{pH}$ (Table 3; Fig. 2). Increasing PGR concentration resulted in a greater reduction in $\mathrm{pH}$ at a carrier water $\mathrm{pH}$ of $6.2,7.2$, and 8.2, but not at 5.3. The largest reduction in $\mathrm{pH}$ of 2.0 units occurred at a CC concentration of 2200 $\mathrm{mg} \cdot \mathrm{L}^{-1}$ and a carrier water $\mathrm{pH}$ of 8.2. When $\mathrm{CC}$ was added to tap water containing bicarbonate, final solution $\mathrm{pH}$ increased as much as $0.3 \mathrm{pH}$ units across all PGR and bicarbonate concentrations.

Daminozide was strongly acidic in reaction. In $\mathrm{RO}$ water, final solution $\mathrm{pH}$ was 4.0 to 4.1 regardless of initial carrier water $\mathrm{pH}$ or PGR concentration (Table 3; Fig. 1). In tap water there was a significant interaction between PGR and bicarbonate concentration on change in $\mathrm{pH}$ (Table 3; Fig. 4). At the lowest bicarbonate concentration, $40 \mathrm{mg}$ $\mathrm{CaCO}_{3} / \mathrm{L}$, the decrease in $\mathrm{pH}$ was similar across all DZ concentrations with final $\mathrm{pH}$ between 4.0 and 4.2. However, the reduction in final solution $\mathrm{pH}$ increased with increasing DZ concentration at bicarbonate concentrations greater than $40 \mathrm{mg} \mathrm{CaCO} / \mathrm{L}$.

Dikegulac-sodium was strongly basic in reaction. Final solution $\mathrm{pH}$ increased by as much $2.2 \mathrm{pH}$ units in $\mathrm{RO}$ carrier water and final solution $\mathrm{pH}$ was 9.0 when DS was added to $\mathrm{RO}$ carrier water at $\mathrm{pH} 8.2$ (Table 3; Fig. 1). In buffered tap water, DS increased solution $\mathrm{pH}$ (Table 3; Fig. 3), although the magnitude of $\mathrm{pH}$ change was reduced compared with $\mathrm{RO}$ water and the highest $\mathrm{pH}$ achieved was 7.8. RO water and tap carrier water both at initial $\mathrm{pH} 6.2$ yielded different results for DS with a final solution $\mathrm{pH}$ of 7.8 (Fig. 1) and 6.8 (Fig. 3), respectively.

Ethephon was strongly acidic in reaction. In $\mathrm{RO}$ water, final solution $\mathrm{pH}$ decreased 2.5 units at carrier water $\mathrm{pH} 5.3$ and almost six units at carrier water $\mathrm{pH} 8.2$ (Table 3; Fig. 1). Final solution $\mathrm{pH}$ ranged from 2.2 to 2.7 . In tap water there was an interaction between EP and bicarbonate concentration (Table 3; Fig. 4). At bicarbonate concentrations of 142 and $293 \mathrm{mg} \mathrm{CaCO} / / \mathrm{L}$ the lowest EP concentration of $250 \mathrm{mg} \cdot \mathrm{L}^{-1}$ decreased final solution $\mathrm{pH}$ much less than did EP concentrations of 500 and $750 \mathrm{mg} \cdot \mathrm{L}^{-1}$. Similarly at a bicarbonate concentration of $293 \mathrm{mg} \mathrm{CaCO}_{3} / \mathrm{L}$, an $\mathrm{EP}$ concentration of $500 \mathrm{mg} \cdot \mathrm{L}^{-1}$, compared with that of $750 \mathrm{mg} \cdot \mathrm{L}^{-1}$, had a diminished effect on final solution $\mathrm{pH}$.

Flurprimidol was nearly neutral in reaction when added to RO water and slightly basic when added to tap water. Final solution $\mathrm{pH}$ was nearly identical to initial carrier water $\mathrm{pH}$ irrespective of FP concentration or initial $\mathrm{pH}$ (Table 3; Fig. 1). In tap water, FP increased $\mathrm{pH} \approx 0.5$ units with no difference resulting from FP concentration and little effect of bicarbonate concentration (Table 3; Fig. 3).

Gibberellic acid was acidic in RO water but weakly basic in tap water. In RO water there was a negligible $\mathrm{pH}$ decrease at initial carrier water $\mathrm{pH} 6.2$ to almost one unit at carrier water $\mathrm{pH} 8.2$ (Table 3; Fig. 1). Gibberellic acid concentration had no effect on the magnitude of $\mathrm{pH}$ change when added to RO water. When GA was added to tap water containing bicarbonate, final solution $\mathrm{pH}$ increased as much as $0.5 \mathrm{pH}$ units, despite a product $\mathrm{pH}$ of 4.0 (Table 1). Gibberellic acid or bicarbonate concentration had no effect on the magnitude of $\mathrm{pH}$ change in tap water (Table 3; Fig. 3). The combination of GA/BA had similar effects as those seen with GA alone (Table 3; Figs. 1 and 3).

Paclobutrazol was nearly neutral in reaction when added to RO water and slightly basic when added to tap water. Final solution $\mathrm{pH}$ was nearly identical to initial carrier water $\mathrm{pH}$ irrespective of $\mathrm{PB}$ concentration or initial $\mathrm{pH}$ (Table 3; Fig. 1). In tap water, $\mathrm{PB}$ increased $\mathrm{pH} \approx 0.5$ units with no difference resulting from $\mathrm{PB}$ concentration and little effect of bicarbonate concentration (Table 3; Fig. 3).

Uniconazole was acidic in reaction. In RO water, the change in $\mathrm{pH}$ increased from 1.3 to $2.4 \mathrm{pH}$ units as UC concentration increased from 10 to $40 \mathrm{mg} \cdot \mathrm{L}^{-1}$ and similarly as initial carrier water $\mathrm{pH}$ increased from 5.3 to 8.2 (Table 3; Fig. 1). In tap water, $\mathrm{pH}$ decreased 0.1 to 1.2 units with increasing UC concentration and decreased 1.1 to 0.4 units with increasing bicarbonate concentration up to $142 \mathrm{mg} \mathrm{CaCO}_{3} / \mathrm{L}$ (Table 3; Fig. 3).

Yates et al. (2011) compiled a list of the manufacturer's recommended $\mathrm{pH}$ range for maximum effectiveness of final spray solutions for each PGR (Table 1). The GA product was the only one of the 11 PGRs studied to provide information regarding carrier water $\mathrm{pH}$ on the label. The GA product label indicated GA is most effective when combined with neutral or slightly acid $\mathrm{pH}$ water. Gibberellic acid $\left(\mathrm{GA}_{3}\right)$ undergoes alkaline hydrolysis when mixed with high $\mathrm{pH}$ water and spray solutions below $\mathrm{pH} 8.0$ resulted in greater 


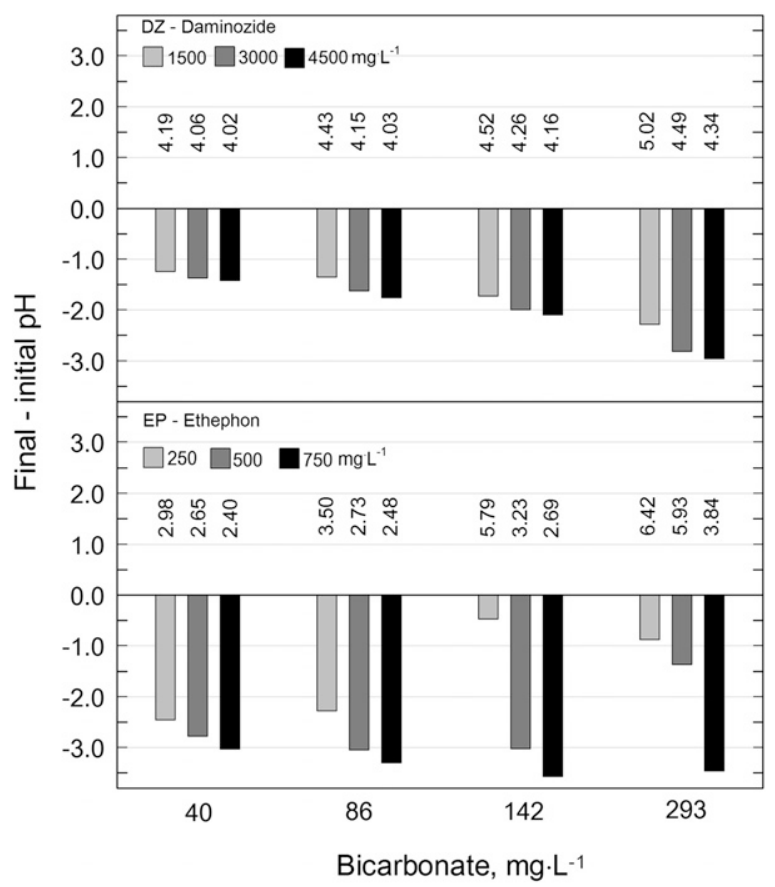

Fig. 4. Change in $\mathrm{pH}$ (final solution $\mathrm{pH}$ minus initial carrier water $\mathrm{pH}$ ) for the interaction of daminozide and ethephon at three solution concentrations and four initial bicarbonate concentrations in tap water. Final solution $\mathrm{pH}$ values are shown above each column.

Table 3. Analysis of variance for the effects of plant growth regulator (PGR) concentration (C), initial carrier water $\mathrm{pH}$, and bicarbonate concentration in reverse osmosis or tap water on change in $\mathrm{pH}$ for 11 PGRs - ancymidol, benzyladenine, chlormequat chloride, daminozide, dikegulac-sodium, ethephon, flurprimidol, gibberellic acid, gibberellic acid/benzyladenine, paclobutrazol, and uniconazole.

\begin{tabular}{|c|c|c|c|c|c|c|}
\hline \multirow[b]{3}{*}{$\begin{array}{l}\text { PGR active } \\
\text { ingredient }\end{array}$} & \multicolumn{3}{|c|}{ Reverse osmosis water } & \multicolumn{3}{|c|}{ Tap water } \\
\hline & \multicolumn{6}{|c|}{ Source of variation } \\
\hline & $\begin{array}{l}\text { PGR } \\
\text { concn } \\
\text { (C) }\end{array}$ & $\begin{array}{c}\text { Initial } \\
\text { carrier } \\
\text { water } \mathrm{pH}\end{array}$ & $\begin{array}{c}\mathrm{C} \times \text { initial } \\
\text { carrier } \\
\text { water } \mathrm{pH}\end{array}$ & $\begin{array}{c}\text { PGR } \\
\text { concn } \\
\text { (C) }\end{array}$ & $\begin{array}{c}\text { Initial carrier } \\
\text { water } \\
\text { bicarbonate } \\
\text { concn }\end{array}$ & $\begin{array}{c}\mathrm{C} \times \text { initial } \\
\text { carrier water } \\
\text { bicarbonate } \\
\text { concn }\end{array}$ \\
\hline & \multicolumn{6}{|c|}{ Level of significance } \\
\hline Ancymidol & 0.11 & $<0.0001$ & 0.97 & 0.001 & $<0.0001$ & 0.23 \\
\hline Benzyladenine & 0.03 & 0.01 & 1.00 & 0.11 & 0.04 & 1.00 \\
\hline $\begin{array}{l}\text { Chlormequat } \\
\text { chloride }\end{array}$ & $<0.0001$ & $<0.0001$ & 0.04 & 0.002 & $<0.0001$ & 0.57 \\
\hline Daminozide & 0.29 & $<0.0001$ & 0.93 & $<0.0001$ & $<0.0001$ & 0.04 \\
\hline Dikegulac-sodium & 0.002 & $<0.0001$ & 0.49 & 0.003 & 0.003 & 1.00 \\
\hline Ethephon & $<0.0001$ & $<0.0001$ & 1.00 & $<0.0001$ & $<0.0001$ & $<0.0001$ \\
\hline Flurprimidol & 0.66 & $<0.0001$ & 0.61 & 0.71 & 0.02 & 0.95 \\
\hline GA & 0.17 & 0.01 & 1.00 & 0.76 & 0.30 & 1.00 \\
\hline GA/BA & 0.19 & 0.01 & 0.97 & 0.98 & 0.42 & 1.00 \\
\hline Paclobutrazol & 0.80 & 0.0001 & 0.99 & 0.64 & 0.01 & 0.99 \\
\hline Uniconazole & $<0.0001$ & $<0.0001$ & 0.75 & $<0.0001$ & $<0.0001$ & 0.07 \\
\hline
\end{tabular}

plant absorption and more stable solutions (Coggins, 2008). This rate of hydrolysis can increase with increasing $\mathrm{pH}$ for susceptible materials (Smith, 2010). Dikegulac-sodium is also susceptible to hydrolysis, but at acidic $\mathrm{pH}$ levels below 6.0 (D. Barcel, personal communication). Unfortunately, there is little information for other PGRs related to performance at various solution $\mathrm{pH}$ and the mechanism by which $\mathrm{pH}$ affects their performance.

Our research found that for several PGRs, the final spray solution $\mathrm{pH}$ was outside of the recommended $\mathrm{pH}$ range. When added to high $\mathrm{pH}$ or high bicarbonate carrier water, the weak acid PGRs such as CC, GA, BA, and GA/BA resulted in a final solution $\mathrm{pH}$ above the maximum recommended $\mathrm{pH}$ of 6.5 . The relatively strong acid, EP, when added at a low concentration to high bicarbonate water had a final solution $\mathrm{pH}$ greater than 5 , also exceeding the recommended range for this PGR. Uniconazole when added to carrier water with moderate to low $\mathrm{pH}$ and low bicarbonate resulted in final solution $\mathrm{pH}$ less than 5.5, the minimum recommended $\mathrm{pH}$ for this PGR. Recommended range should be verified for the basic AC (5.5 to 6.5). Although final solution $\mathrm{pH}$ value was higher than recommended in $\mathrm{RO}$ carrier water at all $\mathrm{pH}$ levels, the range is indicated as "not critical."

Our work identified PGR and carrier water combinations that produce final solu- tion $\mathrm{pH}$ that fall outside of recommended $\mathrm{pH}$ ranges for several acidic PGRs and two basic PGRs. Given the paucity of published data establishing the recommended $\mathrm{pH}$ ranges for these PGRs (except perhaps GA), the effectiveness of these spray solutions on bedding plant growth regulation should be examined in future research. It would also be useful to determine the effect on final solution $\mathrm{pH}$ of commonly tank-mixed products such as CC and DZ and their combined performance.

In summary, most of the 11 PGRs evaluated affected solution $\mathrm{pH}$ when mixed with carrier water varying widely in $\mathrm{pH}$ level and bicarbonate concentration. Bicarbonate reduced carrier water $\mathrm{pH}$ change for both acidic and basic PGRs compared with RO water. Increasing the concentration of several PGRs increased the change in final solution $\mathrm{pH}$. Quantifying bicarbonate concentration as well as carrier water $\mathrm{pH}$ is important in anticipating final solution $\mathrm{pH}$. Establishment of a range of recommended carrier water $\mathrm{pH}$ and bicarbonate levels for these PGRs through efficacy studies on bedding plants is necessary to provide applicators and consultants with accurate information on which to base recommendations for efficient and effective PGR use. It would also provide a basis for future research on water carrier $\mathrm{pH}$ and bicarbonate effects on solutions of new products and on other crops.

\section{Literature Cited}

Barrett, J. 2006. PGR trends: New and novel. 3 Oct 2013. <http://www.gpnmag.com/sites/default/ files/pgrtrendsnew.pdf $>$.

Bell, M. 2001. Bedding plants and seed geraniums. Tips on regulating growth of floriculture crops. O.F.A. Services, Inc., Columbus, OH.

Biernbaum, J. 1999. Water quality. Tips on growing bedding plants. O.F.A. Services, Inc., Columbus, $\mathrm{OH}$.

Buhler, D.D. and O.C. Burnside. 1983. Effect of water quality, carrier volume, and acid on glyphosate phytotoxicity. Weed Sci. 31:163-169.

Burns, C. 2004. Water quality: Is it an issue? 3 Oct. 2013. <http://www.gpnmag.com/water-qualityit-issue $>$.

Chahal, G., J. Roskamp, T. Legleiter, and B. Johnson. 2012. The influence of spray water quality on herbicide efficacy. 3 Oct. 2013. <https://ag. purdue.edu/btny/weedscience/documents/Water_ Quality.pdfs.

Clescerl, L., A. Greenberg, and A. Eaton. eds.1998. Standard methods for the examination of water and wastewater. United Bk. Press, Baltimore, MD.

Cloyd, R.A. 2007. Plant protection. Ball Publishing, Batavia, IL.

Coggins, C. 2008. Citrus Plant growth regulators: General information. 3 Oct. 2013. <http://www. ipm.ucdavis.edu/PMG/r107900111.html>.

Hammer, A. 2001. Calculations. Tips on regulating growth of floriculture crops. O.F.A. Services, Inc., Columbus, $\mathrm{OH}$.

Mudge, K.W. and B.T. Swanson. 1978. Effect of ethephon, indole butyric acid, and treatment solution $\mathrm{pH}$ on rooting and on ethylene levels within mung bean cuttings. Plant Physiol. 61:271-273.

Nickell, L.G. 1994. Plant growth regulators in agriculture and horticulture, p. 9-18. In: Heden, 
P. (ed.) Bioregulators for crop production and pest control. American Chemical Society, Washington, DC.

Smith, T. 2010. Effects of $\mathrm{pH}$ on pesticides and growth regulators. UMass Ext. 3 Oct. 2013. $<$ http://extension.umass.edu/floriculture/factsheets/effects-ph-pesticides-and-growthregulators $>$.
UNH. 2009. ALKCALC Alkalinity calculator. 23 Apr. 2014. <http://extension.unh.edu/ Agric/AGGHFL/alk_calc.cfm>.

Whipker, B.E. 2013. Additional benefits of PGRs. 3 Oct. 2013. <http://www.ballpublishing.com/ pdf/PGR_GUIDE_2013-LowRez.pdf>.

Whipker, B.E., T.J. Cavins, J.L. Gibson, J.M. Dole, P.V. Nelson, and W. Fonteno. 2003. Growth regulators, p. 85-112. In: Hamrick, D. (ed.). Ball Redbook crop production Vol. 2. Ball Publishing, Batavia, IL.

Yates, R., J. Lutz, and V. Brubaker. 2011. Optimum pesticide spray water $\mathrm{pH}$ using Indicate 5 . Griffin Greenhouse and Nursery Supplies, Inc. 3 Oct. 2013. <http://www.ggspro.com/new/ pdfs/Opt-Pest-Spray.pdf>. 